\title{
Losing Direction: the ICTY Appeals Chamber's Controversial Approach to Aiding and Abetting in Perišić
}

\author{
Antonio Coco - Tom Gal*
}

\begin{abstract}
On 28 February 2013 the ICTY Appeals Chamber acquitted Momčilo Perišić, former Chief of Staff of the Yugoslav Army. He had been convicted at trial for having aided and abetted through the provision of weapons and personnel - the crimes committed by the Army of the Republika Srpska in Sarajevo and Srebrenica. The Appeals Chamber found that, when the accused is remote from the crime scene, the prosecution must show that he/she specifically directed his/her assistance towards the perpetration of specific crimes and not generally towards the realization of activities which could be either lawful or unlawful. On 23 January 2014 a different bench of the ICTY Appeals Chamber, in Šainović et al., rejected this theory and affirmed that specific direction is not an element of aiding and abetting in customary international law. This article explores the origins of 'specific direction' and concludes that although it is mentioned in some ICTY judgments, it has never been applied in the sense propounded by the Perišić appeal judgment. Given that the issue remains a source of debate in the jurisprudence, the authors consider the merits of both positions and question whether the temporal or geographical location of the alleged aider and abettor should change the legal elements of the mode of liability. They examine the implications of requiring that the provision of assistance must be directed towards unequivocally unlawful activities and conclude that requiring specific direction blurs the lines between aiding and abetting - an accessory mode of liability - and forms of principal perpetration.
\end{abstract}

\section{Introduction}

On 28 February 2013, the ICTY Appeals Chamber surprised the international community by offering a new reading of the legal requirements for aiding and abetting liability in the case against Momčilo Perišić. The Appeals Chamber found that, when the accused is remote from the 
crime scene, the prosecution must show that he/she specifically directed his/her assistance towards the perpetration of specific crimes and not generally towards the realization of activities which could be either lawful or unlawful. As a result, the Appeals Chamber overturned Perišić's conviction, acquitting him of all counts and vacating his 27 years sentence. ${ }^{1}$ Less than a year later, on 23 January 2014, a differently composed bench of the ICTY Appeals Chamber overturned the Perišić precedent, finding that specific direction is not an element of aiding and abetting liability. ${ }^{2}$ A similar position had been adopted by the Judges of the SCSL in the Charles Taylor appeal judgment. ${ }^{3}$

Yet the Šainović judgment does not necessarily signal an end to the debate on specific direction. The issue remains alive in the ICTY cases, and nothing precludes the possibility that specific direction might be revived by another bench. In the Perišić case, the ICTY Prosecution has now brought a motion seeking reconsideration of Perišić's acquittal, arguing that it was based on an error of law. ${ }^{4}$ This opens up the possibility that four of the five original Perišić Appeals Chamber judges might be called on to address the matter again. The fifth judge has retired and been replaced, leaving open the possibility that a new majority accepts to reconsider the position on specific direction. ${ }^{5}$ The specific direction issue is also crucial for the responsibility of some defendants who are now before other benches of the Appeals Chamber. ${ }^{6}$ In this paper, the authors explore the standard of specific direction and confirm the Šainović view that this is a new

\footnotetext{
*Antonio Coco and Tom Gal are PhD candidates at the University of Geneva and Teaching Assistants at the Geneva Academy of International Humanitarian Law and Human Rights. The authors would like to thank Guido Acquaviva, Jean-Baptiste Maillart, Yael Vias-Gvirzman and the anonymous reviewers for their useful comments on earlier drafts of the article. Many thanks also to Ilya Nuzov and Katie Weir for their comments on the language. A special thanks to Paola Gaeta for her encouragement and supervision. Any errors are the authors' responsibility [antonio.coco@geneva-academy.ch; tom.gal@geneva-academy.ch]

${ }_{1}^{1}$ Judgment, Perišić (IT-04-81), Appeals Chamber, 28 February 2013. Perišić had also been convicted by the Trial Chamber on counts of superior responsibility, ex art. 7(3) ICTYSt., for having failed to punish crimes committed by his subordinates in the Zagreb region. However, the Appeals Chamber overturned this conviction as well, lacking evidence of Perišić's effective control over the perpetrators. See $\S \S 86-120$.

${ }^{2}$ Judgment, Šainović et al. (IT-05-87), Appeals Chamber, 23 January 2014, §§ 1617-1651.

${ }^{3}$ Judgment, Taylor (SCSL-03-01-A), Appeals Chamber, 26 September 2013, §§ 471-480.

${ }^{4}$ Motion for Reconsideration, Perišić (IT-04-81), Office of the Prosecutor, 3 February 2014.

${ }^{5}$ Order Assigning a Judge to a Case before the Appeals Chamber, Perišić (IT-04-81), President of the Tribunal, 5 February 2014.

${ }^{6}$ Two defendants were acquitted due to lack of specific direction in Judgment, Stanišić and Simatović (IT-03-69), Trial Chamber, 30 May 2013. The issue is also relevant for some of the defendants in the Popović et al. case, awaiting the appeal judgment. See Judgment, Popović et al. (IT-05-88), Trial Chamber, 10 June 2010. Of note, specific direction was raised by the Defence in the Đorđević case, but the Appeals Chamber decided not to address aiding and abetting, having considered the totality of the defendant's conduct to covered by his participation in a Joint Criminal Enterprise. See Judgment, Đorđević (IT-05-87/1), Appeals Chamber, 27 January 2014, §§ 825-834.
} 
element, at variance with the consistent interpretation of aiding and abetting adopted by the ICTY in its previous jurisprudence and crystallized in customary international law.

The present article provides, first, a short account of the Perišić Appeals Chamber's reasoning concerning aiding and abetting, and the contrary position advanced in the Śainović appeal judgment and SCSL appeal judgment in the Taylor case (Section 2). It reviews, then, the features of aiding and abetting liability in international criminal law prior to the Perišić appeal judgment, trying to understand the origin of the concept of specific direction and its role in the ICTY jurisprudence (Section 3). Section 4 delves into the logical consistency of the specific direction requirement, exploring its possible repercussions. The authors conclude, in Section 5, that the specific direction requirement undermines the hierarchy of modes of participation by making it easier to prove principal participation than accessory aiding and abetting.

\section{The Jurisprudential Debate on Specific Direction}

\section{A. A Bench Divided: the Reasoning of the Appeals Chamber in Perišić}

In a 4-1 majority judgment, the ICTY Appeals Chamber overturned the Trial Chamber judgment and found Perišić not guilty of aiding and abetting war crimes and crimes against humanity crimes committed by the Army of Republika Srpska ('VRS', for 'Vojska Republike Srpske') in Srebrenica and Sarajevo. The Prosecution argued that Perišić, as Chief of Staff of the Army of the Federal Republic of Yugoslavia ("VJ", for 'Vojska Jugoslavije'), aided and abetted crimes by knowingly providing assistance to the VRS, mainly by means of supplying weapons and personnel. The ICTY Trial Chamber had found Perišić guilty of these charges, Judge Moloto dissenting.

The key distinction between the trial and appellate approaches was the characterization of the actus reus of aiding and abetting: while for the Trial Chamber it was sufficient to prove that the assistance lent by Perišić as VJ Chief of Staff had a substantial effect on the crimes committed by the VRS in Sarajevo and Srebrenica, for the Appeals Chamber this was not enough. ${ }^{7}$ Given Perišić's remoteness from the place where the alleged offences were committed (he was generally based around Belgrade, Serbia, whilst crimes were being committed in Bosnia-

\footnotetext{
${ }^{7}$ See Perišić, supra note $1, \S \S 37$ and $41-42$.
} 
Hercegovina), the Appeals Chamber stated that in order to uphold Perišić's conviction, the Appeals Chamber needed "evidence establishing a direct link between the aid provided by an accused individual and the relevant crimes $[\ldots] " .8$ In other words, evidence that Perišić provided assistance to the VRS, and that the VRS used it in the commission of crimes, would not suffice to establish the actus reus of aiding and abetting. It should have been shown, instead, that the assistance was directed specifically and unequivocally to the crimes committed by the VRS.

Though the very idea of 'direction' would seem to imply an inquiry into the defendant's state of mind, the Appeals Chamber was clear in saying — at least in the main body of the judgment that specific direction does not affect the mens rea for aiding and abetting, well settled in the ICTY jurisprudence as knowledge that the assistance provided would be used in the perpetration of a crime. ${ }^{9}$

The Appeals Chamber based its legal reasoning on an excerpt from the Tadić appeal judgment, affirming that the aider and abettor 'carries out acts specifically directed to assist, encourage or lend moral support to the perpetration of a certain specific crime. ${ }^{10}$ According to the Perišić majority, the Tadić appeal judgment's definition of aiding and abetting has been followed in the subsequent ICTY jurisprudence, which quotes Tadić and mentions the requirement of specific direction in several instances. ${ }^{11}$ The Appeals Chamber explained that the many ICTY judgments that did not mention or apply 'specific direction' did not alter this position because such cases either did not offer a comprehensive definition of aiding and abetting, or concerned defendants who were proximate to the crimes of the principal perpetrators. ${ }^{12}$ The Perišić majority also explained away the two previous ICTY appeal judgments that dismissed arguments concerning 'specific direction'. In Blagojević et al., the Appeals Chamber had affirmed that specific direction 'will often be implicit in the finding that the accused has provided practical assistance

\footnotetext{
${ }^{8}$ Ibid., $\S 44$.

${ }^{9}$ Perišić also argued that aiding and abetting requires, as part of the subjective element, the purpose of facilitating the crime. See Public Redacted Version of the Appeal Brief, Perišić (IT-04-81-A), 12 April 2012, §§ 167-191. The issue was not analysed by the Appeals Chamber, given its finding on specific direction. See also ICCSt, art. 25(3)(c), analysed infra, Section 4.A.

${ }^{10}$ Judgment, Tadić (IT-94-1), Appeals Chamber, 15 July 1999, § 229, cited in Perišić, supra note 1, § 26. Emphasis added.

${ }^{11}$ Ibid., $\S \S 28-29$.

${ }^{12}$ Ibid., $\S \S 30$ and 38.
} 
to the principal perpetrator which had a substantial effect on the commission of the crime. ${ }^{13}$ This quotation supports the Prosecutor's argument in Perišic that specific direction has no independent meaning, but is rather a part of the ordinary actus reus requirement for a substantial contribution. ${ }^{14}$ The Perišić majority reasoned instead that, since specific direction is only 'often' implicit, then at least sometimes it must be analysed and proven separately. ${ }^{15}$ The Mrkšić et al. appeal judgment went even further than Blagojević et al., explicitly stating that specific direction is not an essential ingredient of aiding and abetting liability. ${ }^{16}$ According to the Perišić majority, however, the Mrkšić et al. appeal judgment neither intended to depart from the well-settled ICTY jurisprudence on specific direction, nor provided adequate reasons to do so. ${ }^{17}$

Based on these considerations, the Perišić Appeals Chamber concluded that the Trial Chamber erred when not requiring and analysing specific direction as an element of aiding and abetting. Therefore, the Appeals Chamber had to reassess whether Perišić's role in providing assistance to the VRS made him liable as an aider and abettor. ${ }^{18}$ The Appeals Chamber agreed with the Trial Chamber that the VRS was not hierarchically subordinated to the VJ and that the VJ troops seconded to the VRS were not under the effective control of Perišić. ${ }^{19}$ The Appeals Chamber found that the assistance policy was not initiated by Perišić. Rather, it was set at a higher political level - the Supreme Defence Council (SDC) of the Federal Republic of Yugoslavia (FRY). ${ }^{20}$ This was not necessarily sufficient to relieve Perišić of criminal liability: if the policy was criminal as such, then its implementation would have automatically satisfied the specific direction requirement. The Appeals Chamber concluded, however, that the policy was aimed at

\footnotetext{
${ }^{13}$ Judgment, Blagojević and Jokić (IT-02-60), Appeals Chamber, 9 May 2007, § 189. The case concerned Vidoje Blagojević and Dragan Jokić, officials of the VRS in Bosnia-Hercegovina, charged on various counts of crimes against humanity, war crimes and (Blagojević only) complicity in genocide. As to the mode of liability, the prosecution tried to demonstrate the defendants' participation in a JCE, whose common plan included forcible transfers and mass executions. Interestingly, since it could not be shown that the accused shared the requisite intent, the Trial Chamber found them responsible for aiding and abetting. See also Judgment, Trial Chamber, 17 January $2005, \S \S 749-760$ and $770-775$.

${ }^{14}$ Perišić, supra note $1, \S 21$.

${ }^{15} \mathrm{Ibid} ., \S \S 31$ and 33.The interpretation is followed in Stanišić and Simatović, supra note $6 \S 1264$.

${ }^{16}$ Judgment, Mrkšić et al. (IT-95-13-1), Appeals Chamber, 5 May 2009, § 159.

${ }^{17}$ Perišić, supra note $1, \S \S 32-36$. The Perišić Appeals Chamber, in particular, defined the Mrkšić finding just as 'an attempt to summarise, in passing, the Blagojević and Jokić Appeal Judgement's holding [...] rather than abjure previous jurisprudence establishing that specific direction is an element' ( 34$)$. The majority cited, in support of its argument, a passage from Judgment, Lukić and Lukić (IT-98-32/1), Appeals Chamber, 4 December 2012, § 424. This particular interpretation of the Blagojević, Mrkšić and Lukić jurisprudence was expressly rejected in Sainović, supra note 2, $\S 1619-1622$.

${ }_{18}^{18}$ Perišić, supra note $1, \S \S 41-44$.

${ }^{19} \mathrm{Ibid}$., § 46.

${ }^{20} \mathrm{Ibid}$., § 51 .
} 
supporting and assisting the VRS — an army waging war, not a criminal organisation ${ }^{21}$ — and its general war effort, not specific crimes. The magnitude of the assistance could have served at best as circumstantial evidence that the assistance was indeed directed to the crimes, but was not sufficient alone to establish the required link. ${ }^{22}$

The Appeals Chamber then analysed Perišić's behaviour when implementing the policy. It concluded that Perišić did support the continuance of the SDC assistance policy towards the VRS, but only as far as it concerned the general war effort. ${ }^{23}$ Although Perišić had discretion in determining the assistance to be provided, such discretion was not used to lend assistance to specific criminal activities. ${ }^{24}$ The fact that VJ soldiers seconded to the VRS had later committed crimes in Srebrenica and Sarajevo was not enough to prove the existence of the specific direction element. ${ }^{25}$ The Appeals Chamber found that Perišić rejected any request for assistance submitted outside the official channels and urged the punishment of VJ soldiers who provided such unauthorized aid. ${ }^{26}$ In light of the available evidence, the Appeals Chamber concluded that it was not proven beyond reasonable doubt that Perišić had carried out acts of assistance specifically directed to the commission of crimes in Sarajevo and Srebrenica. ${ }^{27}$ The fact that Perišić had knowledge of those crimes did not have any weight in this assessment. ${ }^{28}$

Four judges issued separate opinions, variously concurring and dissenting. Although all judges but one acquitted Perišić, there was no agreement among them as to the precise meaning of 'specific direction'. Out of the five Appeals Chamber judges, only one actually viewed specific direction as an essential component of the actus reus required to establish the aiding and abetting liability, as described in the majority judgment. In their joint separate opinion, Judges Agius and Meron explained that the requirement of specific direction should logically fall within the mental element. However, this approach was limited by the fact that the ICTY had already explicitly rejected a purpose requirement for mens rea, analogous to specific direction, and affirmed that

\footnotetext{
${ }^{21}$ Ibid., $\S 53$.

${ }^{22}$ Ibid., $§ 56$.

${ }^{23}$ Ibid., $\$ 60$.

${ }^{24}$ Ibid., $\S \S 61$ and 65.

${ }^{25}$ Ibid., $\$ 63$.

${ }^{26}$ Ibid., $\$ 67$.

${ }^{27}$ Ibid., \$ 69.

${ }^{28}$ Ibid., $\$ 68$.
} 
aiding and abetting only requires knowledge of the contribution's effect. ${ }^{29}$ Clearly, however, Judges Meron and Agius in fact saw specific direction as a purposive mens rea, fulfilled when an individual 'specifically aimed to assist relevant crimes'. 30

By contrast, Judges Ramaroson and Liu contested the very existence of the specific direction requirement. Judge Ramaroson pointed out that in Tadić the ICTY Appeals Chamber was merely trying to differentiate between joint criminal enterprise and aiding and abetting liability and did not envisage specific direction as an essential component of the actus reus. ${ }^{31}$ She conceded, similarly to the Joint separate opinion of Judges Agius and Meron, that should specific direction be considered a requirement for aiding and abetting, it would logically belong to the subjective element. However, she noted that the geographical or temporal distance from the final crime should not be decisive when defining aiding and abetting liability. In her view, specific direction is either always required for aiding and abetting, or it is never required. ${ }^{32}$ In the end however, Judge Ramaroson supported Perišić's acquittal due to lack of evidence. Judge Liu, in contrast, rejected specific direction as an element of aiding and abetting. He argued that the majority was introducing an additional requirement, never analysed in previous cases, which would make it more difficult to convict those 'responsible for knowingly facilitating the most grievous crimes. $^{, 33}$

\section{B. A quick reversal: Taylor and Šainović et al. reject specific direction}

The Perišić re-interpretation of aiding and abetting liability did not make it far. Just a few months after the Perišić judgment was issued, the Special Court for Sierra Leone (SCSL) Appeals Chamber rejected the specific direction requirement in the Taylor judgment. At first glance, the factual background in the Taylor case resembles Perišić's. Charles Taylor, the former

\footnotetext{
${ }^{29}$ Joint Separate Opinion of Judges Theodor Meron and Carmel Agius, Judgment, Perišić (IT-04-81), Appeals Chamber, 28 February 2013, §3.

${ }^{30}$ Ibid. N. Farrell, 'Attributing Criminal Liability to Corporate Actors: Some Lessons from the International Tribunals', 8 Journal of International Criminal Justice (JICJ) (2010) 873-894, at 890, warned against this interpretation.

${ }^{31}$ Opinion Séparée du Juge Ramaroson sur la Question de la Visée Spécifique dans la Complicité par Aide et Encouragement, Judgment, Perišić (IT-04-81), Appeals Chamber, 28 February 2013, § 2-4.

32 Ibid, $\S \S 7-8$.

${ }^{33}$ Partially Dissenting Opinion of Judge Liu, Judgment, Perišić (IT-04-81), Appeals Chamber, 28 February $2013, \S$ 3.
} 
President of Liberia, was charged with aiding and abetting crimes in Sierra Leone. ${ }^{34}$ Taylor's Defence claimed - using Perišić as support - that, given the defendant's geographical remoteness from the crimes, specific direction should have been established as part of the objective element of aiding and abetting. Since the available evidence did not show beyond reasonable doubt that Taylor specifically directed his acts of assistance towards the perpetration of the crimes, counsel argued, he should have been acquitted. ${ }^{35}$

The SCSL Appeals Chamber rejected the defence arguments, noting that it was not obliged to follow the ICTY Appeals Chamber jurisprudence. ${ }^{36}$ After an analysis of customary international law and of the SCSL Statute, the Appeals Chamber found that nothing required specific direction for aiding and abetting liability. ${ }^{37}$ It suggested that the ICTY Perišić Appeals Chamber did not apply customary international law on aiding and abetting, but rather followed certain ICTY precedents on the point. The SCSL Appeals Chamber, moreover, doubted whether the case law cited in Perišić actually supports the specific direction requirement. Finally, the SCSL Appeals Chamber denied any legal relevance to the geographic location of the defendant in aiding and abetting cases. ${ }^{38}$ Having rejected the need for specific direction, the SCSL Appeals Chamber affirmed Charles Taylor's conviction for aiding and abetting. ${ }^{39}$

In the Šainović case, a differently composed bench of the ICTY Appeals Chamber agreed with the SCSL and reversed the position adopted eleven months earlier in Perišic. ${ }^{40}$ All four defendants had been convicted for crimes committed in Kosovo during the year 1999. The issue of aiding and abetting was relevant to the case of the accused Lazarević, convicted by the Trial Chamber for his knowing contribution to the crimes of deportation and other inhumane acts (forcible transfer) as crimes against humanity. ${ }^{41}$ The majority (Judge Tuzmukhamedov dissenting $^{42}$ ) found the Appeals Chamber's conclusion in Perišić to be at odds with previous

\footnotetext{
${ }^{34}$ Taylor, supra note $3, \S \S 8-9$.

${ }^{35}$ Ibid., $\S \S 467-471$.

${ }^{36}$ Ibid., $\$ 472$.

${ }^{37}$ Ibid., $\$ \S 473-475$.

${ }^{38}$ Ibid., $\S \S 476-480$.

39 Ibid., $\$ 481$.

40 Šainović, Appeal Judgment, supra note 2.

41 Ibid.. $§ 1605$.

42 Judge Tuzmukhamedov declined to take a position on specific direction, arguing instead that it was not necessary to determine the issue on the facts of the case because Lazarević, commander of the VJ's Pristina corps stationed in Kosovo, was not geographically remote from the crime scene. See, Dissenting opinion of Judge Tuzmukhamedov,
} 
ICTY Appeals Chamber judgments. ${ }^{43}$ It first emphasised that, prior to the Perišić appeal judgment, "no independent specific direction requirement was applied by the Appeals Chamber to the facts of any case before it' but only 'substantial contribution as an element of the actus reus has consistently been required' ${ }^{44}$ Then, after having reviewed post World-War II judgments, relevant national legislation and other international law sources (such as the ILC Draft Code of 1996), the Appeals Chamber reached the conclusion that 'specific direction' is not an essential element of the actus reus of aiding and abetting in customary international law. ${ }^{45}$

\section{Contextualizing the Specific Direction Debate: The Elements of Aiding and Abetting Liability in International Criminal Law prior to Perišić}

\section{A. The Basic Elements of Aiding and Abetting}

'Aiding and abetting' is one of several possible modes of participating in a criminal offence. Its origins can be found in domestic systems. ${ }^{46}$ Thus far, the statutes of all international criminal tribunals have included jurisdiction over aiding and abetting responsibility. ${ }^{47}$ Of importance to our analysis, Article 7(1) of the ICTY Statute acknowledges the individual criminal responsibility of every person who 'planned, instigated, ordered, committed or otherwise aided and abetted in the planning, preparation or execution of a crime'. However, the Statute lacks any further elaboration of this form of accessory liability. In the landmark Furundžija judgment, an ICTY Trial Chamber undertook a thorough review of aiding and abetting in customary international law, contributing greatly to the clarification of its legal elements. ${ }^{48}$

The Furundžija Trial Chamber's analysis of aiding and abetting largely defined the mode prior to the Perišić appeal judgment's addition of 'specific direction'. According to the Furundžija case, and the subsequent jurisprudence, the objective element of aiding and abetting is to provide

$\S \S 40-47$. The majority, in footnote 5320, explained that the issue of specific direction was explicitly raised by the Parties and that it was a legal issue of 'general significance to the Tribunal's jurisprudence'.

${ }^{43}$ Ibid., $\$ \S 1621-1622$.

${ }^{44}$ Ibid. $\$ 1625$.

${ }^{45}$ Ibid., $\S \S 1627-1648$ (analysis of the cases) and $\S \S 1649-1650$ (conclusion).

${ }^{46}$ It is the common law expression referring to the concept of complicity. See W. Schabas, The International Criminal Court: A Commentary on the Rome Statute (Oxford: Oxford University Press, 2010), at 434.

${ }^{47}$ See e.g. Art. 7(1) ICTYSt.; Art. 6(1) ICTRSt.; Art. 25(3)(c) ICCSt.; Art. 6(1) SCSLSt.

48 Judgement, Furundžija (IT-95-17/1), Trial Chamber, 10 December 1998, §§ 193-226 (actus reus) and 236-241 (mens rea), endorsed, inter alia, by Judgment, Blaškić (IT-95-14), Appeals Chamber, 29 July $2004, \S 46$. 
assistance to a crime by making a substantial contribution or having a substantial effect on its perpetration, even if the assistance itself would not amount to a criminal act. "Substantial' means that the assistance has increased the likelihood that the crime could be perpetrated, or that it could be perpetrated in a certain manner. ${ }^{50}$ The provision of the means by which the crime was perpetrated - for example the provision of weapons - has been consistently found to amount to a substantial contribution. ${ }^{51}$ Tacit approval of criminal conduct by a person in a position of authority, present at the crime scene, may amount to aiding and abetting as well. ${ }^{52}$ Aiding and abetting liability might also accrue by means of an omission when the breach of a legal duty substantially contributes to the crime. ${ }^{53}$

As for the subjective element, the aider and abettor, at the moment in which he provided his/her assistance, must have knowledge that the assistance will substantially contribute to the perpetration of the crime. ${ }^{54}$ This knowledge standard does not imply absolute certainty about all the circumstances in which the crime will be perpetrated. Instead, it requires the aider and abettor to accept the risk that — given the circumstances in which assistance is provided - one or more possible crimes could be committed. ${ }^{55}$ The aider and abettor accepts that risk 'knowingly' when he has sufficient information to realize that, in the ordinary course of events, his behaviour will substantially contribute to the crime. ${ }^{56}$ Even though knowledge of all circumstances of the crime is not required, knowledge of the essential elements of the crime that will be possibly perpetrated is necessary. ${ }^{57}$ This includes the knowledge of the principal perpetrator's specific intent, when required (e.g. genocide, persecution as a crime against humanity). ${ }^{58}$ In short, the aider and

\footnotetext{
${ }^{49}$ Ibid., § 235. See also Taylor, supra note 3, § 368. For an overview, see A. Cassese and P. Gaeta, International Criminal Law (3rd edn., Oxford: Oxford University Press, 2013) at 193 ff. See also Schabas, supra note 46.

${ }^{50}$ Judgment, Tadić (IT-94-1), Trial Chamber, 7 May 1997, § 688. This standard is usually deemed to be higher than the 'significant' contribution demanded for a Joint Criminal Enterprise. See Judgment, Kvočka et al. (IT-98-30/1), Appeals Chamber, 28 February 2005, § 97 and Judgment, Gotovina et al. (IT-06-90), Appeals Chamber, 16 November 2012, § 149.

${ }^{51}$ Judgment, Ntakirutimana et al. (ICTR-96-10-A and 96-17-A), Appeals Chamber, 13 December 2004, §530.

${ }^{52}$ Judgment, Brđanin (IT-99-36), Appeals Chamber, 3 April 2007, § 273; Judgment, Kayishema and Ruzindana (ICTR-95-1), Trial Chamber, 21 May 1999, § 202.

${ }_{53}$ Judgment, Simić et al. (IT-95-9), Trial Chamber, 17 October 2003, § 162; Judgment, Orić (IT-03-68), Trial Chamber, 30 June 2006, § 283.

${ }_{54}^{54}$ Mrkšić, supra note 16, § 49. See also Judgment, Orić (IT-03-68), Appeals Chamber, 3 December 2008, § 43.

${ }^{55}$ Judgment, Brima (SCSL-2004-16-T), Trial Chamber, 20 June 2007, § 776; Furundžija, supra note 48, § 246; Judgment, Blaškić (IT-95-14), Trial Chamber, 3 March 2000, § 287.

${ }^{56}$ The Hague Court of Appeal, Judgment, Van Anraat, case $n^{\circ}$ 09/751003-04,9 May 2007, § 11.16.See also Orić, Trial Judgment, supra note 53, § 288.

${ }^{57}$ Furundžija, supra note 48, § 246.

${ }^{58}$ Judgment, Krstić (IT-98-33), Appeals Chamber, 19 April 2004, § 140.
} 
abettor willingly provides the assistance, even though he/she knows that such assistance substantially contributes to the crime. ${ }^{59}$ This is the main difference between aiding and abetting liability and participation in a joint criminal enterprise: unlike a member of a joint criminal enterprise, an aider and abettor does not need to share the principal perpetrator's criminal intent. $^{60}$

\title{
B. The Origin of the Concept of 'Specific Direction'
}

Specific direction was not mentioned by the ICTY in the 1998 Furundžija trial judgment. The language first appeared in the Tadić appeal judgment of 15 July 1999. Having described the three forms of joint criminal enterprise, the Tadić Appeals Chamber went on to clarify the distinction from another mode of participation in criminal conduct, namely aiding and abetting. In the words of the Appeals Chamber:

\begin{abstract}
The aider and abettor carries out acts specifically directed to assist, encourage or lend moral support to the perpetration of a certain specific crime (murder, extermination, rape, torture, wanton destruction of civilian property, etc.), and this support has a substantial effect upon the perpetration of the crime. By contrast, in the case of acting in pursuance of a common purpose or design, it is sufficient for the participant to perform acts that in some way are directed to the furthering of the common plan or purpose. ${ }^{61}$
\end{abstract}

The expressions 'specifically directed' and 'specific crime', are used here in opposition to the 'common plan or purpose' required for JCE which, as is well-known, might either itself amount to a crime under the jurisdiction of the Tribunal, or involve the commission of one or more crimes. $^{62}$

\footnotetext{
${ }^{59}$ See Blaškić, Appeal Judgment, supra note 48, §§ 49-50. This stand was lastly re-affirmed in Taylor, supra note 3, $\S \S 436-440$ and $450-451$.

${ }^{60}$ For a more in-depth analysis of the difference between these two forms of responsibility, see infra, Section 5 .

${ }^{61}$ See Tadić, Appeal Judgment, supra note 10. Emphasis added.

${ }^{62}$ See Judgment, Šainović et al. (IT-05-87), Trial Chamber, 26 February 2009, § 103: 'unlike aiding and abetting, an accused charged with responsibility for a crime or underlying offence due to his participation in a joint criminal enterprise need not act or fail to act in a way that assists, encourages, or lends moral support to another in the perpetration of a crime or underlying offence. Rather, the accused need merely act or fail to act "in some way ...
} 
In Perišić, the Appeals Chamber seized on this reference to 'specifically directed' to develop a new requirement. The better view, as the Šainović Appeals Chamber ultimately concluded, is that the Tadic discussion was not aimed at systematically defining aiding and abetting liability (as was done in Furundžija), but was instead included in order to better defining joint criminal enterprise, by drawing a comparison with another mode of liability. ${ }^{63}$ 'Specific direction' in Tadić is not a stand-alone element of aiding and abetting, but an expression used to clarify the definition of joint criminal enterprise by comparing it with a different mode of liability.

This hypothesis - that the term 'specific direction' was only clarifying language, not part of the objective element - also explains why the ICTY has consistently avoided analysing specific direction as a discrete element of aiding and abetting. In the ICTY jurisprudence, the analysis of whether the provision of assistance is directed to a crime was usually skipped or deemed implicit in the inquiry on its substantial effect. The Appeals Chamber in Blagojevic explained that the finding of specific direction 'will often be implicit in the finding that the accused has provided practical assistance to the principal perpetrator which had a substantial effect on the commission of the crime. ${ }^{64}$ This implies that 'specific direction' is an implicit part of the substantial contribution requirement - namely, the "contribution' ${ }^{65}$ The fact that it has sometimes been analysed explicitly does not change the substance: whenever the accused aider and abettor's contribution has had a substantial effect on the perpetration of the crime, then his/her assistance has been directed to that crime. ${ }^{66}$

Indeed, when answering the accused Jokić's appeal on the existence of a specific direction requirement, the Blagojevic Appeals Chamber almost exclusively dealt with the substantial effect of the contribution itself. Moreover, the Appeals Chamber stated that the exercise of routine duties (which by definition are performed in everyday life, and thus not ordinarily directed to any

directed to the furtherance of the common plan or purpose." See also Judgment, Vasiljević (IT-98-32), Appeals Chamber, 25 February 2004, § 102.

${ }^{63}$ As restated in Judgment, Aleksovski (IT-95-14/1), Appeals Chamber, 24 March 2000, § 163, and lastly in Šainović, supra note $2, \S 1623$.

${ }^{64}$ Blagojević, Appeal Judgment, supra note 13.

${ }^{65}$ Ibid. As confirmed in Šainović, supra note 2, § 1625.

${ }^{66}$ This interpretation seems to be shared by Judge Picard in her dissenting opinion in Stanišić and Simatović, supra note $6, \S 2405$. 
particular crime) does not exculpate the accused if he/she has provided a substantial contribution to the crime. ${ }^{67}$

Consequently, recalling the language used in Mrkšić, the discrete analysis of specific direction is not an essential ingredient of the overall analysis on the actus reus of aiding and abetting. ${ }^{68}$

\section{The Lack of References to Specific Direction in ICTY Cases on Aiding and Abetting} with a Fact Pattern Similar to Perišić

Specific direction was not even mentioned in many important cases discussing the definition of aiding and abetting liability. ${ }^{69}$ In those instances in which it was mentioned, the relevant ICTY Chambers never embarked on an in-depth or discrete analysis of the criterion. ${ }^{70}$ For instance, the appeal judgment in Kvočka et al. quoted the Tadić appeal judgment but, then, when explaining the elements of aiding and abetting liability, did not spend a single word on specific direction. ${ }^{71}$

The Perišić appeal judgment lists a long series of cases in which, due to the purported proximity of the defendant to the crime, specific direction was not an issue. ${ }^{72}$ Nevertheless, the list equates completely different cases, some involving defendants whose proximity to the crimes is at least questionable.

Of note, the ICTY Appeals Chamber did not require specific direction in the Brđanin case concerning a Bosnian Serb politician operating in the Autonomous Region of Krajina (ARK). The Perišić majority considered the defendant to be proximate to the principal perpetrators because he aided the commission of crimes by Bosnian Serb forces in the region under his authority. However, Brđanin was not present at the place where crimes were being committed, and his conduct was in many ways similar to Perišić's. He was convicted by the Trial Chamber as an aider and abettor on several counts of crimes against humanity and war crimes (including wilful killing, torture, forcible transfer and deportation), precisely because of his role in decisions

\footnotetext{
${ }^{67}$ Blagojević, Appeal Judgment, supra note 13. In this sense, see Farrell, supra note 30, at 883.

${ }^{68}$ Mrkšić, supra note 16, § 159.

${ }^{69}$ See Krstić, Appeal Judgment, supra note 58, § 144; Judgment, Naletilić (IT-98-34) Trial Chamber, 31 March 2003, § 63; Judgment, Mucić et al. (IT-96-21), Trial Chamber, 9 October 2001, § 326; Judgment, Vasiljević (IT-9832), Trial Chamber, 29 November 2002, § 70; Blagojević Trial Judgment, supra note 13, §§ 726 and 782.

${ }^{70}$ See e.g. Vasiljević, Appeal Judgment, supra note 62, §§ 102 and 135.

${ }^{71}$ See Kvočka et al., supra note 50, §§ 89-90.

${ }^{72}$ See Perišić, supra note $1, \S 38$ and footnote 100.
} 
of the ARK crisis staff, which led to the disarmament and resettlement of non-Serbs in the region, and because of his inaction toward the atrocities committed in some detention centres. ${ }^{73}$ The Appeals Chamber partially allowed Brđanin's appeal with respect to his tacit assistance towards crimes committed in the detention facilities, but not because specific direction was lacking. What the appeal judges found to be lacking was evidence that the defendant's inaction and attitude actually encouraged the perpetration of acts of torture. The prosecution could not demonstrate that, on those counts, Brđanin had contributed to the perpetration of the offences by lending moral support or encouragement. ${ }^{74}$ If he had done so knowingly, he could have been convicted without any further inquiry into the specific direction of his assistance. On the other hand, the Appeals Chamber confirmed the defendant's liability as aider and abettor on the other counts as a result of the policy of disarmament and resettlement that he had endorsed and implemented, creating the condition for those crimes to be perpetrated. Maybe, in the Brđanin case, specific direction was implicit in the nature of the assistance lent. However this requirement was not analysed at all, despite the fact that the defendant's proximity to the crimes was not so obvious.

The Appeals Chamber similarly found Radislav Krstić to be responsible for genocide as an aider and abettor because of his failure to prevent the troops and resources under his authority (he was Chief of Staff of the VRS Drina Corps) from being used to facilitate the crimes in Srebrenica. ${ }^{75}$ Also in this case the Perišić Appeals Chamber contended that the defendant was somehow proximate to the crimes. This contention disregards the fact that Krstic was not present at the locus commissi delicti, and the troops and resources in question could have well been used - in theory - in lawful acts of warfare. If specific direction had been a requirement, the Krstic Appeals Chamber would have at least acknowledged it. Nonetheless, the judges only looked at whether Krstić's knowing conduct did in fact end up being a substantial contribution to the perpetration of international crimes. Since it was, he was found responsible as an aider and abettor. $^{76}$

\footnotetext{
${ }^{73}$ Judgment, Brđanin (IT-99-36), Trial Chamber, 1 September 2004, §§ 471-475, 530-538, 578-583, 664-670 $673-$ 678, and 1052-1061.

${ }_{75}^{74}$ Brđanin, Appeal Judgment, supra note 52, §§ 272-286.

${ }_{76}^{75}$ Krstić, supra note 58, $\S \S 135-144$.

${ }^{76}$ Ibid., $§ 238$.
} 
The Perišić appeal judgment was correct when saying that specific direction establishes a culpable link between the assistance and the crime ${ }^{77}$ However, the ICTY case law shows that the link between the assistance provided and the crime is also known as 'contribution', and that whether such contribution is culpable or not only depends on the presence of the requisite mens rea ${ }^{78}$ It is beyond the purposes of this article to assess whether, on the basis of the evidence available, Perišić did in fact contribute to the crimes committed by the VRS in Srebrenica and Sarajevo. However, if he did, then his assistance was necessarily 'specifically directed' to them.

\section{A Critical Appraisal of the Specific Direction Requirement}

\section{A. A Comparison between the Perišić Standard and Other Sources Hinting at the} Existence of the 'Specific Direction' Requirement

One may wonder why the Perišić majority read the ICTY jurisprudence differently and considered 'specific direction' to be a discrete element of the conduct required to establish the liability of the accused. One commentator has suggested that the Perišić majority's reading is in line with the International Law Commission's 1996 Draft Code of Crimes against the Peace and the Security of Mankind. ${ }^{79}$ Article 2(3)(d) of the Draft Code affirms the individual criminal responsibility of every person who 'knowingly aids, abets or otherwise assists, directly and substantially, in the commission of such a crime, including providing the means for its commission. ${ }^{80}$ The use of the word 'directly', here, might suggest specific direction. However, this reading of the Draft Code is questionable. The ILC Commentary explains that 'directly and substantially' point to a kind of assistance that 'facilitates the commission of a crime in some significant way. ${ }^{, 81}$ If 'in some significant way' explains 'substantially', then 'directly' is explained by 'facilitates the commission of the crime'. Thus, the 'direction' requirement does not refer to the aim of the author, but to the objective link between the assistance provided and the crime, the link usually defined as 'contribution'.

\footnotetext{
${ }^{77}$ Perišić, supra note $1, \S 37$.

${ }^{78}$ In the same vain, Farrell, supra note 30 , at 891.

${ }^{79}$ K.J. Heller, 'The SCSL's Incoherent - and Selective - Analysis of Custom', Opinio Juris, 27 September 2013, at http://opiniojuris.org/2013/09/27/scsls-incoherent-selective-analysis-custom/ (last visited 17 February 2014).

80 The 1996 ILC Draft Code of Crimes against the Peace and the Security of Mankind, Yearbook of the International Law Commission, 1996, vol. II, Part Two, Art. 2(3)(d). Emphasis added.

${ }^{81}$ Ibid., at 21, §11. Emphasis added.
} 
The standard adopted by the Perišic Appeals Chamber does not coincide with the ICC definition either. ${ }^{82}$ Art. 25(3)(c) reads: ' $[F]$ or the purpose of facilitating the commission of such a crime, aids, abets or otherwise assists in its commission or its attempted commission, including providing the means for its commission.' This provision can be interpreted in two ways.

According to the first reading, Article 25(3)(c) introduces the need for the aider and abettor to share the principal offender's mens rea, since it entails the willingness to increase the likelihood that the crime is committed. This interpretation would necessarily blur the line between aiding and abetting and any form of joint perpetration. By elevating the mens rea requirement, the ICC Statute would depart from customary international law on this point.

David Scheffer has offered however a second reading of Article 25(3)(c), trying to reconcile it with the customary definition of aiding and abetting. He argues that the 'purpose' language is the result of a compromise, and that it either recalls the well-established knowledge standard ${ }^{83}$ or, if it recalls shared intent, this can be reasonably inferred from the mere fact of providing assistance in the knowledge of its likely criminal results. ${ }^{84}$

None of the two different interpretations of Article 25(3)(c), however, justifies the stand taken by the Perišic Appeals Chamber. Even accepting the first interpretation, i.e. that ICC aiding and abetting requires a purpose, this cannot explain the ICTY Appeals Chamber's identification of 'specific direction' as an ingredient of the actus reus. Moreover, Article 25(3)(c) does not draw any difference between remote and proximate aiders and abettors, and it does not require that acts of assistance are lent precisely and exclusively for the commission of unlawful activities.

\section{B. Does the Geographical or Temporal Position of the Alleged Aider and Abettor Make}

\section{a Difference?}

The Appeals Chamber in Perišić affirmed that specific direction can be presumed or implied for those aiders and abettors who are proximate to the crime (geographically or otherwise), while the requirement must be analysed and proven separately for those who are remote from it. According

\footnotetext{
${ }^{82}$ Article 25(3)(c) ICCst.

${ }^{83}$ D.J. Scheffer, 'Brief of David J. Scheffer, Director of the Centre of International Human Rights, as Amicus Curiae in Support of the Issuance of a Writ of Certiorari' in the case Presbyterian Church of Sudan v. Talisman Energy Inc. before the Supreme Court of United State, case No. 69-1262, 19 May 2010, at 18-19.

${ }^{84}$ Ibid., at 21-22.
} 
to the Appeals Chamber, this might explain why most ICTY judgments mentioning specific direction have never analysed it as a discrete ingredient of aiding and abetting.

In the 13 May 2013 hearing on the Śainović et al. case, the ICTY Office of the Prosecutor strongly disagreed with this view. ${ }^{85}$ First, the Prosecution argued that this difference has no basis in the ICTY Statute or in its jurisprudence. Second, it would create an unjustified difference in treatment based on the location of the accused at the time when the assistance was given and the crime perpetrated. Thirdly, proximity or remoteness should, in theory, have no influence on the substantial effect of the accused's conduct, nor on his mens rea. As remarked by the Prosecution, a 'remote' aider and abettor might even be able to provide more effective assistance than a 'proximate' aider and abettor, and have a more extensive knowledge of the circumstances of the crimes, especially if he/she is a high ranking official of an army involved in a conflict. Finally, the exact meaning of the proximity or remoteness has been left undefined by the Perišić appeal judgment, which only referred to an assessment to be conducted on a case-by-case basis. ${ }^{86}$ Such vagueness undermines the ability of potential defendants to foresee the proscribed conduct. It also makes prosecution more difficult by requiring proof beyond reasonable doubt of an element whose contours are far from clear.

Additionally, the ICTY jurisprudence has previously never relied on geographical or temporal proximity to modify the elements of guilt. In Krajišnik, the accused appealed his conviction on the basis that he was remote from the crime scene. The Appeals Chamber labelled the question as legally irrelevant. ${ }^{87}$ Even though the Krajišnik case concerned convictions for joint criminal enterprise, the approach taken by the Chamber is instructive with regard to aiding and abetting. Geographical or temporal proximity might have an impact on the ability of the prosecution to prove that a factual contribution was made, but does not mark any legal difference. The distinction is also morally insignificant. ${ }^{88}$ The only proximity that has ever mattered for aiding

\footnotetext{
85 Śainović, supra note 2, hearing 13 March 2013, transcript, at 454. The whole rejection of the specific direction requirement by the OTP can be found at $440-461$.

${ }^{86}$ Perišić, supra note $1, \S 40$.

${ }^{87}$ Judgment, Krajišnik (IT-00-39), Appeals Chamber, 17 March 2009, § 663.

${ }^{88}$ See Stewart J. G., "The ICTY Loses its Way on Complicity - Part 1", Opinio Juris (3 April 2013) available at http://opiniojuris.org/2013/04/03/guest-post-the-icty-loses-its-way-on-complicity-part-1/ (last visited on 17 February 2014).
} 
and abetting liability is the legal one, expressed by the objective link of substantial contribution plus the subjective link of the knowledge of its likely effects. ${ }^{89}$

In other well-known aiding and abetting cases the proximity/remoteness of the accused was not an issue, or at least not from an actus reus perspective. In the landmark Zyklon B case, ${ }^{90}$ mentioned both in the Perišić appeal judgment and in the Furundžija trial judgment, ${ }^{91}$ the fact that the three accused were remote from the crime scene was not part of the court's reasoning and was actually never analysed. ${ }^{92}$ Similarly, in the Van Anraat case, the proximity of the accused to the crime scene (geographically, not temporally) only mattered for the purposes of the mens rea: the fact that Frans Van Anraat - a Dutch businessman who provided chemical components to the Iraqi government during the ' $80 \mathrm{~s}$ - found himself in Iraq was just additional evidence of his knowledge of the circumstances in which Iraq would have used his supplies. ${ }^{93}$ These two cases, among the others, may be deemed to reflect state practice in interpreting and applying the law on aiding and abetting international crimes, considering the special circumstances in which these crimes occur.

Of course, both the geographical location of an aider and abettor with respect to the locus commissi delicti and the temporal distance between the assistance and the crime may play a factual role in determining whether a person is responsible for aiding and abetting. One can imagine circumstances in which it might be easier to prove the mens rea of a person if he was

\footnotetext{
${ }^{89}$ See Tadić Trial Judgment, supra note 50, § 687: "Thus not only does one not have to be present but the connection between the act contributing to the commission and the act of commission itself can be geographically and temporally distanced.". See also $§ 688$ :"Even in these cases, where the act in complicity was significantly removed from the ultimate illegal result, it was clear that the actions of the accused had a substantial and direct effect on the commission of the illegal act, and that they generally had knowledge of the likely effect of their actions." See also Mucić Trial Judgment, supra note 69, § 327, and Aleksovski Appeal Judgment, supra note 63, § 62. See also Farrell, supra note 30, at 877.

${ }^{90}$ Trial of Bruno Tesch and Two Others (hereafter, 'Zyklon B case'), British Military Court, Hamburg, 1-8 March 1946, Vol. I, Law Reports, at 93. The accused - the owner of a firm manufacturing the gas 'Zyklon B' gas and two of his collaborators - were charged for supplying the gas to the $S S$ while knowing that it would have been used to kill Allied nationals interned in concentration camps. The verdict was founded on three cumulative elements: first, recognizing the $S S$ as a criminal organization under the definition of the Charter (i.e. determining its acts to be criminal); second, determining that all the accused knew how the Zyklon B gas was being used by the SS; third, acknowledging the contribution of the accused to the killings, through the actual delivery of the gas to the SS. Bruno Tesch and his assistant Karl Weinbacher were found guilty. However the third accused, Joachim Drosihn, was acquitted due to the fact that, despite knowing the destination of the gas, he made no contribution to its actual shipment and transfer.

${ }^{91}$ Respectively, Perišić, supra note 1, fn 115, § 44; Furundžija, supra note 48, § 222.

${ }^{92}$ The British Court however, did consider information of encounters between the accused and their client, i.e. the SS, to prove the existence of the mens rea. Zyklon B case, supra note 90, at 95.

${ }^{93}$ Van Anraat, supra note 56, § 11.14-11.16.
} 
located on the crime scene or to establish the substantial effect of assistance provided immediately before the perpetration of the crime. However, these factual and evidentiary considerations, unlike the legal distinction in the Perišic appeal judgment, do not change the elements required for aiding and abetting liability.

\section{Is it Correct to Require Assistance to Be Unequivocally Lent to Purely Unlawful}

\section{Activities?}

The Appeals Chamber in Perišić contended that 'the provision of general assistance which could be used for both lawful and unlawful activities will not be sufficient, alone, to prove that this aid was specifically directed to the crimes of the principal perpetrators'. ${ }^{94}$ In other words the majority seems to say that, in case the assistance could also be used for lawful activities, the accused would not be considered responsible as an aider and abettor, even if it is proven that the accused substantially contributed the commission of the crime.

This position is unconvincing. Firstly, as explained in earlier ICTY cases, this disregards the previous stand taken by the ICTY jurisprudence on the kind of assistance which might constitute aiding and abetting. Dragan Jokić argued on appeal that the assistance he provided could have been reasonably directed to lawful purposes, and therefore his responsibility had not been proven. The Appeals Chamber categorically refused to accept this argument, confirming that as long as the assistance constituted a substantial contribution to the crime it did not matter whether it could have also been used to facilitate lawful activities. According to the Appeals Chamber, this was an issue of motive, irrelevant as to both the actus reus and the mens rea of aiding and abetting. ${ }^{95}$ In this same sense, the defendants in the Second World War Zyklon B case had claimed that the gas used to kill concentration camp inmates was provided for lawful purposes (i.e. to eliminate

\footnotetext{
${ }^{94}$ Perišić, supra note $1, \S 44$.

${ }^{95}$ Blagojević Appeal Judgment, supra note 13, § 202: 'The Trial Chamber found, and the Appeals Chamber confirmed, that Jokić substantially contributed to the mass executions when he sent engineering equipment to the execution sites and that he did this knowing that the equipment would be used to dig mass graves for the victims. Even if Jokić were concerned about public safety and health, this would not change the fact that his actions substantially contributed to the crimes or the conclusion that he did so with knowledge that his actions would assist the organizers of the "murder campaign". Rather his arguments go to the issue of motive. The Appeals Chamber recalls that personal motives are immaterial for the purposes of assessing an accused's intent and criminal responsibility.'
} 
parasites and pathogens). ${ }^{96}$ However, the British military court adjudicating the case highlighted that, while the gas could well have been used for lawful purposes, the defendants knew that the gas was to be used for killing people in the concentration camps. ${ }^{97}$ The fact that the defendants had trained the SS personnel to use the gas in such a manner was considered as evidence of the existence of the required mens rea, but had no influence on the assessment of the objective element of the conduct. ${ }^{98}$

This brings us to the second possible criticism: requiring acts of assistance to be aimed at facilitating exclusively unlawful activities conflates the consideration of the actus reus with an enquiry into the defendant's state of mind. This enquiry would not be consistent with the mens rea standard undisputedly used by the previous ICTY jurisprudence (and crystallized in customary international law): knowledge. It would instead point to the motivations for which assistance is provided, which - at least when specific intent is not required - are completely irrelevant in international criminal law.

Thirdly, the stand taken by the Appeals Chamber in Perišic does not fit well with aiding and abetting through omission. Omission may result in encouraging or facilitating a specific crime when there is a legal duty to act. But it is hard to construe omission - inaction - as 'specifically directed' to something. It would require the prosecutor to show that the omission could not have resulted in anything else but the final crime. But failing to act, when there is a duty to do so, does not always result in the perpetration of a crime.

Fourthly, it is doubtful whether, in real life, there is any kind of assistance which can be used exclusively for unlawful activities. Let us consider the case of a person who lends a gun to a friend, being aware that the latter is a violent person just released from jail and looking for a fast way to make easy money. Even in that case it is not sure that the gun will be used in a robbery,

${ }^{96}$ Zyklon B case, supra note 90 , at 97-98.

${ }^{97}$ Inter alia, because of the large quantities to be delivered. Ibid.

${ }^{98} \mathrm{Ibid}$. K.J. Heller, in 'The Specific Direction Requirement would not Have Acquitted the Zyklon B Defendants', Opinio Juris, 2 June 2013, at http://opiniojuris.org/2013/08/19/no-specific-direction-would-not-have-acquitted-thezyklon-b-defendants/ (last visited 17 February 2014), notes that, in any case, specific direction need not have been proven in the Zyklon $B$ case, since the SS had been declared to be a criminal organization for the purposes of the Nuremberg IMT Charter, and assistance lent to a criminal organization would be criminal per se under the IMT Charter system. See International Military Tribunal of Nuremberg (IMT), Judgment, Goering et al., 30 September-1 October 1946, at 95-96. That determination, however, was intended to have value only for the purposes of the IMT Charter, and did not intend to equate the SS to classic criminal organizations (e.g. the Italian Mafia). Moreover, this determination remained a unique case in the history of international criminal justice, and should not be used as a comparison for the criminality of some of the VRS activities. 
since it could be used for lawful activities, e.g. in self-defence. The Perišić appeal judgment implies that assistance given to criminal organizations should be treated as being directed to unlawful activities. However, even this consideration is not entirely true to the extent that members of criminal organizations may be engaged daily in a broad range of lawful activities. ${ }^{99}$

This issue arises mostly for acts of so-called 'neutral assistance', namely conduct that, while seeming harmless on its face (e.g. transferring money or seconding personnel), did in fact contribute to a crime. The fact that these acts might be used for both lawful and unlawful activities does not mean that they do not entail criminal responsibility where they were provided knowingly and had an actual, substantial effect on the perpetration of the crime by the beneficiaries of that assistance. ${ }^{100}$ Moreover, provision of weapons - as a peculiar kind of assistance — is never 'neutral'. According to a District Court Judge in New York:

The provision of goods specifically designed to kill, to inflict pain, or to cause other injuries resulting from violations of customary international law bear a closer causal connection to the principal crime than the sale of raw materials or the provision of loans. Training in a precise criminal use only further supports the importance of this link. Therefore, in the context of commercial services, provision of the means by which a violation of the law is carried out is sufficient to meet the actus reus requirement of aiding and abetting liability under customary international law. ${ }^{101}$

Critics of this approach could say that any provision of weapons would result in the individual criminal responsibility of the provider, approaching a form of strict liability. However, this fear is unfounded. In order for aiding and abetting liability to arise, a number of additional elements need to be present: one or more crimes must have been actually perpetrated; the weapons provided must have substantially contributed to the perpetration; and the weapons-provider must

\footnotetext{
${ }^{99}$ In the same vain, Stewart, supra note 88.

${ }^{100} \mathrm{Cf}$. H. Vest, 'Business leaders and Modes of Individual Criminal Responsibility', 8 JICJ (2010), 851-872, at 863864. In this sense, also Taylor, supra note $3, \S 395$.

${ }^{101}$ In re South African Apartheid Litigation, 8 April 2009, 2009 WL 960078 (S.D.N.Y.) at 21. Cited in Farrell, supra note 30 , at 891 .
} 
have been aware of their likely use. The fact that they could have theoretically been used in lawful activities would not be decisive in this assessment. ${ }^{102}$

\section{Blurring the Line between Aiding and Abetting and Joint Perpetration?}

The inclusion of 'specific direction' as an ingredient of the actus reus of aiding and abetting would bring it closer to certain forms of joint perpetration of international crimes. The objective element of a joint criminal enterprise (JCE), for example, is met when there is a common plan shared by a plurality of persons - which amounts to or involves the commission of international crimes, and a participant has given a significant contribution to the realization of that common plan. ${ }^{103}$ Each participant needs to share the intent to realize the common objective and the crimes involved. ${ }^{104}$ In the Krajišnik case, the ICTY Appeals Chamber explained that the shared intent could be inferred when an accused was informed that the common objective included the perpetration of some crimes, and nonetheless failed to take any effective measure to prevent them. ${ }^{105}$

Let us imagine the case of a non-state armed group, which is engaged in an armed conflict against its own state and regularly perpetrates international crimes. A second state (not taking part in the conflict) wants to sustain the military effort of that armed group by providing weapons and personnel. A high-level member of the government of this second state knows that the weapons and personnel are being used, not only in the armed struggle, but also to commit international crimes, and nonetheless willingly continues to provide the assistance. Since he accepts the crimes as necessary means to achieve the common objective, he does not take any steps to stem their commission. In this scenario, the government official could be convicted as a participant in a JCE as long as it is proven that he shared the common goal involving the perpetration of the crimes. However, if that is not the case, according to the Perišić approach, he

\footnotetext{
${ }^{102}$ Even more so in the case of Perišić, according to Prosecutor: the attacks against civilians in Sarajevo and Srebrenica were so central to the VRS's overall military strategy that it would have been impossible to contribute to the VRS's war effort without contributing to such crimes. See Perišić, supra note 1, § 24.

${ }^{103}$ See Tadić Appeal Judgment, supra note 10, § 228.

${ }^{104}$ Ibid. On JCE in general, see Cassese, Gaeta, International Criminal Law, supra note 49, at 163-175. See also Cryer et al., An Introduction to International Criminal Law and Procedure ( $2^{\text {nd }}$ ed., Cambridge: Cambridge University Press, 2010), at 367-373.

${ }^{105}$ Krajišnik Appeal Judgment, supra note 87, § 203, accepting the position expressed in the trial judgment. See Judgment, Krajišnik (IT-00-39), Trial Chamber, 27 September 2006, § 1098.
} 
could not be convicted for a lesser form of responsibility (aiding and abetting) as his acts of assistance are not exclusively used in the commission of the crimes. Paradoxically, in such cases, either the defendant is found to be a perpetrator, or he would not be held accountable otherwise. The mode of liability potentially resulting in a harsher sentence might end up being the only one that the Prosecutor can reasonably prove, unlike the one resulting in a lesser sentence.

At the ICC, in contrast, the jurisprudence seems to maintain a rational hierarchy within the modes. ${ }^{106}$ According to the ICC Trial Chamber in the Lubanga case, an accused can be found responsible as a co-perpetrator under Article 25(3)(a) in presence of an agreement between the participants and of an essential contribution demonstrating control over the crime. ${ }^{107}$ On the contrary, an accused can be deemed responsible as an aider and abettor under Article 25(3)(c) whenever, even in the absence of an essential contribution, he/she aided, abetted or otherwise assisted the commission of a crime. It is not clear whether the ICC will interpret the provision as punishing any kind of contribution, thus departing from customary international law on the point, or whether instead it will require the contribution to be 'substantial'. ${ }^{108}$

On the mens rea side the co-perpetrator needs, first, to be aware and to accept the risk that acting in furtherance of the common plan may, in the ordinary course of events, result in the perpetration of the crime. Second, the co-perpetrator needs to be aware that the contribution is in fact essential to the realization of the crime. ${ }^{109}$ As regards aiding and abetting, as seen supra, Article 25(3)(c) might be interpreted as requiring the purpose of facilitating the perpetration of the crime. ${ }^{110}$ In this last case, the mens rea standard for aiding and abetting would be very similar to the one required for co-perpetration, except for the common agreement between the participants.

The ICC however maintains a proper distinction between the co-perpetrator and the aider and abettor, delineated by the different thresholds for the actus reus: co-perpetration requires an essential contribution whereas aiding and abetting requires — at maximum — a substantial

\footnotetext{
${ }^{106}$ Contra, see Separate Opinion of Judge Fulford, Lubanga (ICC-01/04-01/06), Trial Chamber, 14 March 2012, $\S$ 8-11, and Concurring Opinion of Judge Van den Wyngaert, Ngudjolo Chui (ICC-01/04-02/12), Appeals Chamber, 18 December 2012, $\S \S 22-30$.

${ }^{107}$ Judgment, Lubanga (ICC-01/04-01/06), Trial Chamber, 14 March 2012, §§ 999-1003.

${ }^{108}$ According to an eminent commentator, the change would not be'of much great practical importance'. See Cryer, supra note 104, at 377.

${ }^{109}$ Lubanga, supra note $107, \S \S 1012-1013$.

${ }^{110}$ See supra, Section 4.A.
} 
contribution. Though the distinction between these two qualifications might be subtle, it will still be easier to prove that a contribution constitutes aiding and abetting, rather than co-perpetration. Moreover, for aiding and abetting there would be no need to show the existence of a common agreement.

However, if the ICC were to follow the Perišić approach to aiding and abetting to require that the contribution is exclusively directed to specific unlawful activities, this might lead to a paradoxical conclusion. Let us imagine that a person - who has not personally carried out the criminal conduct and is remote from the crime - has willingly provided an essential contribution to the perpetration of a crime, knowing that she has increased the likelihood of the crime, in furtherance of a common agreement. Though in fact essential, her contribution could nevertheless have been used for lawful purposes. Under the ICC Lubanga jurisprudence, provided that the existence of a criminal agreement is proven, she would be considered to be a co-perpetrator. In case the common plan is not proven, however, under the ICTY Perišić jurisprudence she could not be convicted as an aider and abettor, because the actus reus requirement is so high that not even an essential contribution would fulfil it.

Unfortunately, while defining the contours of aiding and abetting liability, the Perišić Appeals Chamber narrowed the definition so much that aiding and abetting responsibility will be more difficult to prove than some forms of joint perpetration. This goes against one of the purposes of

accessory liability: to hold criminally accountable all those who knowingly helped in the perpetration of a crime, even though there is insufficient proof that they personally perpetrated or shared the intent to perpetrate the crime. Accessory liability logically results in the imposition of less restrictive legal requirements for a lesser form of individual criminal responsibility. The Perišić approach overturns this logic.

\section{Final Remarks}

We have recently witnessed the Special Court for Sierra Leone and the ICTY Appeals Chamber itself rejecting the interpretation proposed in the Perišić judgment. ${ }^{111}$ It remains to be seen whether, in the upcoming cases, the ICTY Appeals Chamber will follow the approach taken in

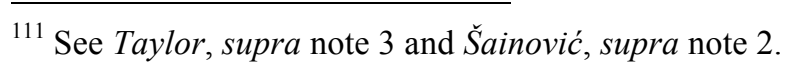


the Šainović judgment or whether, instead, a differently composed bench will try to re-introduce specific direction. It is very much hoped, however, that the ICTY Appeals Chamber will not resuscitate the Perišić approach to aiding and abetting, taking into account the problems of specific direction and its possible repercussions. Indeed, considering the shape of recent armed conflicts, and the more frequent involvement of external actors in internal conflicts, the Perišić theory risks erasing the criminal responsibility of all those who - safe in their offices knowingly and substantially contribute to the perpetration of international crimes. 